\title{
Eco enzyme and its benefits for organic rice production and disinfectant
}

\author{
Yaya Hasanah*, Lisa Mawarni, Hamidah Hanum \\ Faculty of Agriculture, Universitas Sumatera Utara, Jl. Prof. A. Sofyan No 3 Kampus USU, Medan 20155
}

\begin{abstract}
Eco enzyme is a fermented liquid from organic waste fruits, vegetables, and other organic waste which is very useful for agriculture, health, and households. One of Deli Serdang villages that are very vulnerable to Covid-19 is Karang Anyar Village, located in Beringin District, only about $5 \mathrm{~km}$ from Kuala Namu International Airport. On the other hand, in Karang Anyar Village, there is a Mekar Pasar Kawat farmer group that cultivates organic rice that needs liquid organic fertilizer (LOF). This community service aims to educate the public about using an eco enzyme from household waste as liquid organic fertilizer (LOF) and disinfectant. Implementing community service that is carried out is training and practice of making eco enzyme and its benefits, direct practice of demonstration plot of rice cultivation by utilizing eco enzyme as LOF. The results are training and mentoring in making eco enzyme based on household waste, training and hands-on practice on applying eco enzyme in the environment as disinfectant, training, and direct demonstration plot rice cultivation by utilizing eco enzyme produced as organic fertilizer liquid.
\end{abstract}

Keywords: Eco enzyme, Disinfectant, Liquid organic Fertilizer, Organic rice

\begin{abstract}
Abstrak. Eco enzyme merupakan cairan fermentasi dari limbah organik buah-buahan, sayuran dan sampah organik lainnya yang sangat bermanfaat untuk pertanian, kesehatan dan bagi rumah tangga. Salah satu desa di Deli Serdang yang sangat rentan terdampak Covid-19 adalah Desa Karang Anyar yang terletak di Kecamatan Beringin, hanya sekitar $5 \mathrm{~km}$ dari Bandar Udara Internasional Kuala Namu. Pada sisi lain, di Desa Karang Anyar terdapat kelompok tani Mekar Pasar Kawat yang mengupayakan padi organik yang sangat membutuhkan pupuk organik cair. Tujuan pengabdian kepada masyarakat ini yaitu mengedukasi masyarakat tentang pemanfaatan eco enzyme dari limbah rumah tangga sebagai pupuk organik cair (POC) dan desinfektan. Metode pelaksanaan pengabdian masyarakat yang dilakukan yaitu pelatihan dan praktek pembuatan eco enzyme dan manfaatnya,
\end{abstract}

*Corresponding author at: Jl. Prof. A. Sofyan No 3 Kampus USU, Medan 20155

E-mail address: yaya@usu.ac.id 
praktek langsung demplot budidaya padi dengan memanfaatkan eco enzyme sebagai POC. Hasil pengabdian yang telah dicapai yaitu pelatihan dan pendampingan dalam pembuatan eco enzyme berbasis limbah rumah tangga, pelatihan dan praktek langsung cara aplikasi eco enzyme di lingkungan sebagai desinfektan, pelatihan dan praktek langsung demplot budidaya padi dengan memanfaatkan eco enzyme yang dihasilkan sebagai pupuk organik cair.

Kata Kunci: Eco enzyme, Desinfektan, Pupuk organik cair, Padi organik Received 27 August 2020| Revised 14 September 2020| Accepted 27 November 2020

\section{Introduction}

Deli Serdang Regency is one of the areas included in the red zone for the spread of Covid-19, apart from Medan and Tanjung Balai. The three regions have high population density and community mobility [1]. Karang Anyar Village is one of the villages in Deli Serdang that is very vulnerable to Covid-19. It is located in Beringin District, only about $5 \mathrm{~km}$ from Kuala Namu International Airport, considering that the airport is visited by people from various nations who may be carriers of the virus.

On the other hand, in Karang Anyar Village, there is a farmer group Mekar Pasar Kawat, which is cultivating organic rice. The problems are public concern about the dangers of exposure to the Covid-19 virus and difficulties in increasing organic rice production. Organic agricultural products must have food safety attributes, high nutritional attributes, and friendly environmental (eco-labelling attributes). The shift in people's preferences towards a healthy lifestyle has resulted in a rapid increase in demand for agricultural products [2][3].

Eco enzyme is one way that can be used as an organic waste-based disinfectant to prevent the spread of the Covid-19 virus. Eco enzyme is a fermented liquid from organic waste of fruits, vegetables, vegetable stalks, and other organic waste which has many benefits [4][5][6]. The benefits of eco enzymes are divided into three, namely for agriculture (as liquid organic fertilizer, vegetable pesticides), for health (as a disinfectant, cleaning fluid), for households (as a substitute for bath soap, floor cleaner, mouthwash) [7][8].

In anticipation of the spread of the Covid-19 virus, an eco enzyme is believed to kill harmful viruses in the air. An eco enzyme's advantage is that it is environmentally friendly and does not harm the body [9], following the WHO's warning that spraying chemical disinfectants on the body's surface cannot kill viruses that have entered the body. This action is dangerous because the content of chlorine, alcohol, and hydrogen 
peroxide can be dangerous if it comes in contact with the skin. Thus, the solution is that people use eco enzyme solutions as a substitute for chemical disinfectants.

One of the ingredients is acetic acid which can kill germs, viruses, and bacteria. Also, eco enzymes contain protease, lipase, and amylase enzymes that can kill pathogens [10][11]. Besides, an eco enzyme can also function as liquid organic fertilizer [12][13], which can fertilize organic rice plants, which are residents' livelihoods in the Mekar Pasar Kawat farmer group. Until now, 15 ha of land has been cultivated for organic rice cultivation, with average dry grain productivity of $7.5 \mathrm{t} / \mathrm{ha}$. The Mekar Pasar Kawat farmer group has passed the Organic Certification (LSO LeSOS) for rice and secondary crops.

Mixing eco enzyme with water when used for watering plants will promote better yields and repel pests. Meanwhile, the fermented organic waste residue can be used as an excellent organic fertilizer.

Based on the analysis of the situation, several of partners' problems in preventing the spread of Covid-19 and increasing organic rice production are the availability of disinfectant liquid which is increasingly rare and expensive on the market. Also, the availability of liquid organic fertilizers to increase rice production needs to be improved. So far, farmers use liquid organic fertilizer made from cow dung, which is increasingly scarce, so it needs to be replaced by other natural materials that function as liquid organic fertilizer.

Based on the analysis of the situation and problems of the partners, the priority matters to be addressed include the manufacture and use of eco enzyme as an environmentally friendly disinfectant to prevent the spread of Covid-19 and the use of eco enzyme as liquid organic fertilizer and vegetable pesticides in to increase organic rice production in partner farmer groups. It should briefly explain the background of the study and research objectives, which no more than $20 \%$ of the total page; provide a short review of the pertinent literature, state the originality of the research, and state the research objectives. This section also covers the real and actual problems, challenges, or requirements needed by the community-related to the research purposes.

\section{Method}

Based on partners' problems, empowerment efforts that can be done are producing eco enzyme based on household waste as a disinfectant in preventing the spread of 
Covid-19. Eco enzyme also acts as liquid organic fertilizer to increase organic rice production in farmer groups, considering the eco enzyme is a product that is safe to use, environmentally friendly. Utilization of household waste-based eco enzyme as disinfectant and liquid organic fertilizer is expected to solve partner problems in preventing the spread of Covid-19, which is very dangerous and in the context of increasing organic rice production. Liquid organic disinfectants and fertilizers produced from eco-enzyme based on household waste can also be sold to increase farmer group members' family income.

The approach method that will be carried out to support community service programs' realization to partners is participatory empowerment, which includes lectures and discussions (training), mentoring, monitoring evaluation, and assistance with materials and tools. The method used in this program is in the form of :

a. Workshop and discussions (training)

Materials for lectures and discussions were socialization to partners about Eco enzyme: characteristics, benefits, advantages, manufacturing methods, and application methods as a disinfectant and liquid organic fertilizer. The lecture material is:

- Making eco enzyme based on household waste. Lecturer: Dr Ir. Yaya Hasanah. The materials used for making eco enzyme consist of $500 \mathrm{ml}$ of water; $50 \mathrm{~g}$ of molasses (brown sugar); 150 fruit waste. Tools used: $1000 \mathrm{ml}$ plastic bottles; digital scales; funnel; knife. How to make eco enzyme :

1. Prepare a used plastic bottle/container that can be closed tightly. Do not use metal containers ad they are less elastic. The fermentation process will produce gas, so it requires a clean container.

2. Put $500 \mathrm{ml}$ of water into a plastic bottle/container, followed by $50 \mathrm{~g}$ of molasses.

3. Put the remaining fruit peels or vegetable scraps into the container.

4. Please leave it in the room from the fermentation process. Do not fill the container full. Stir or turn your plastic bottle/container upside down until the water and sugar/molasses solution is mixed well. Please don't shake it.

5. In the first month, gas will be produced from the fermentation process. Stir or turn the plastic container/bottle upside down, unscrewing the plastic container/bottle every day for the first month. Sometimes there is a white coating on the surface of the solution. If worms appear, add a handful of sugar, mix well and then cover. 
6. Store in a cool, dry, and ventilated place. Avoid direct sunlight and do not store it in the refrigerator. Fermentation lasts for three months (for tropical areas) and six months (for subtropical regions).

7. After three months, filter the eco enzyme using a strainer. The residue can be reused for a new batch of eco enzyme production by adding fresh bins. The residue can also be dried, then blended, and buried in the soil as the fertilizer or disinfectant.

- Utilization and application of eco enzyme as a disinfectant.

Lecturer: Dr Ir. Lisa Mawarni.

- Utilization and application of eco enzyme as liquid organic fertilizer.

Lecturer: Dr Ir. Hamidah Hanum, MP.

The community service team also provided assistance in the direct practice of making eco enzyme based on household waste and its use and application in the surrounding environment as a disinfectant to prevent the spread of the Covid-19 outbreak and also act as liquid organic fertilizer.

Because it is still in the Covid-19 pandemic condition, which requires social and physical distancing, the lecture and discussion meetings (training) refer to the Government's procedures. The forum is not more than 30 people. So it is carried out in stages, and interactive media are used such as Youtube and articles and brochures about eco enzyme.

b. Direct practice:

- Making eco enzyme as a disinfectant and liquid organic fertilizer

- The practice of cultivating organic rice on land using an eco enzyme as liquid organic fertilizer.

This community service activity requires active participation from both parties. The Higher Education (USU) plays an active role in empowering partners by carrying out transferring technology from universities to partners. Likewise, partners play an active role in implementing community service in providing a place for training locations, organic rice cultivation, care, and maintenance of organic rice plants. Sites for making disinfectants and liquid organic fertilizers from eco enzymes that are expected to play a role in preventing the very dangerous spread of Covid-19, also increase organic rice production.

The realization of this community service program is also expected to be able to foster an entrepreneurial spirit (Entrepreneurship) among partners and provide innovation (technology transfer) from universities (USU) to partners through partner empowerment 
through making eco enzyme based on household waste and its role as a disinfectant and organic liquid fertilizer.

\section{Result and Discussion}

\subsection{Lectures and discussions}

Activities that have been carried out in this community service program are:

a. Preparation phase

- Hold team discussions about training plans and training materials to be provided.

- Call back the Mekar Pasar Kawat Group Chairman to determine the time and place for community service implementation.

b. Implementation Stage

At this stage, training is carried out in the following order of events:

- Making eco enzyme based on household waste. Lecturer: Dr Ir. Yaya Hasanah.

- Utilization and application of eco enzyme as a disinfectant. Lecturer: Dr Ir. Lisa Mawarni.

- Utilization and application of eco enzyme as liquid organic fertilizer. Lecturer: Dr Ir. Hamidah Hanum, MP.

- Discussion and question and answer with the training participants.

\subsection{Direct practice of cultivating organic rice using eco enzyme}

The growing organic rice method using eco enzyme is carried out in the paddy fields belonging to the Mekar Pasar Kawat farmer group (Sukardi Ariyanto), which includes the stages of preparation for and locations of implementing activities.

a. Activity Preparation Stage

- Hold a team discussion to discuss the preparation plan for eco-enzyme-based organic rice cultivation.

- Contact, hold a discussion with the head of the Mekar Pasar Kawat farmer group regarding the location of organic rice cultivation practice.

- Determine the location of organic rice cultivation activities.

- Prepare tools and suitable materials in the form of rice seeds, rice nurseries, hoes.

b. Activity Implementation Stage 
- Organic rice cultivation is based on an eco enzyme in the Mekar Pasar Kawat farmer group. The technology stages of organic rice cultivation based on the eco enzyme :

- Preparation of paddy fields for organic rice cultivation

- Perform soil cultivation

- Create a mobile irrigation channel and manufacture drainage and drainage gates.

- Plant rice seeds first with a row cropping pattern (2: 1), let stand for two weeks.

- Choose rice seeds that are immersion-resistant, for example, Ciherang.

- Rice seeds are planted after 17-20 days in the nursery

- The application of eco enzyme is carried out for $500 \mathrm{ml} / 12$ litres of water, which is 15 to 65 days after transplanting with a duration of once in 3 weeks.

3.2 Hand over the technology transfer

In this community service activity, technology transfer items were handed over in the form of a plastic tank with a lid, a knapsack sprayer, and a scale. It is hoped that the handover of this technology transfer will improve the quality of eco-enzyme-based organic rice in farmer groups.

After completing the training and direct practice, an activity evaluation is carried out. Based on the assessment of the activities carried out, about $80 \%$ of farmers understand how to make and use an eco enzyme, and $95 \%$ of farmers are interested in making the next eco enzyme for liquid organic fertilizer and disinfectant.
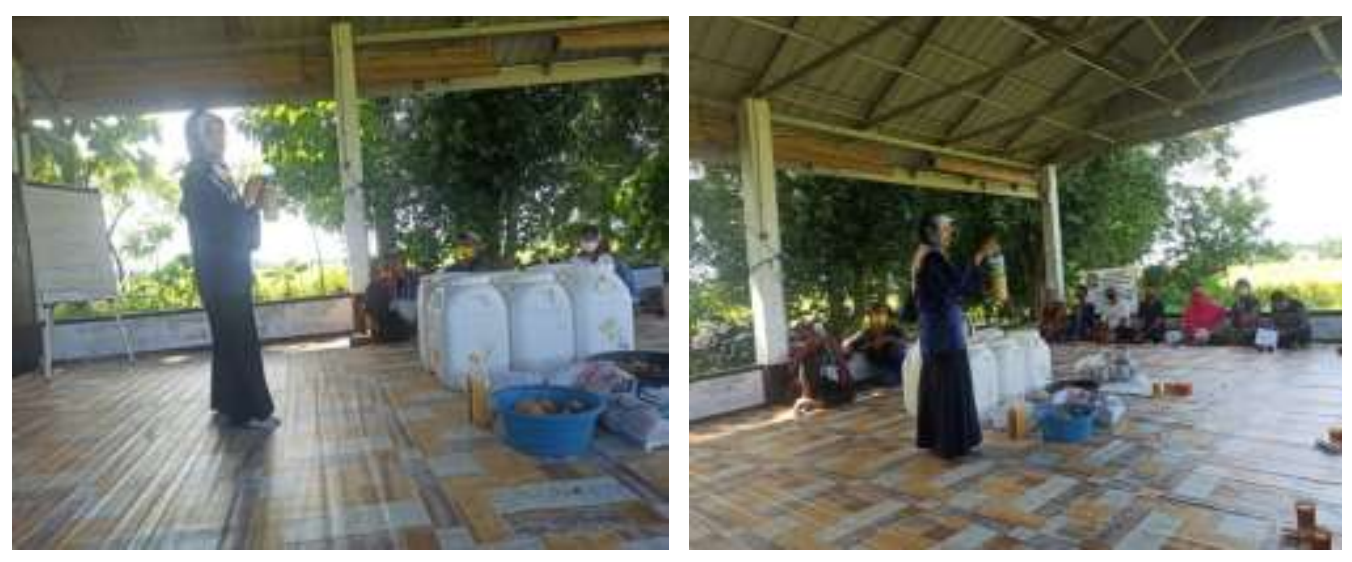

Figure 1. Training in making an eco enzyme 

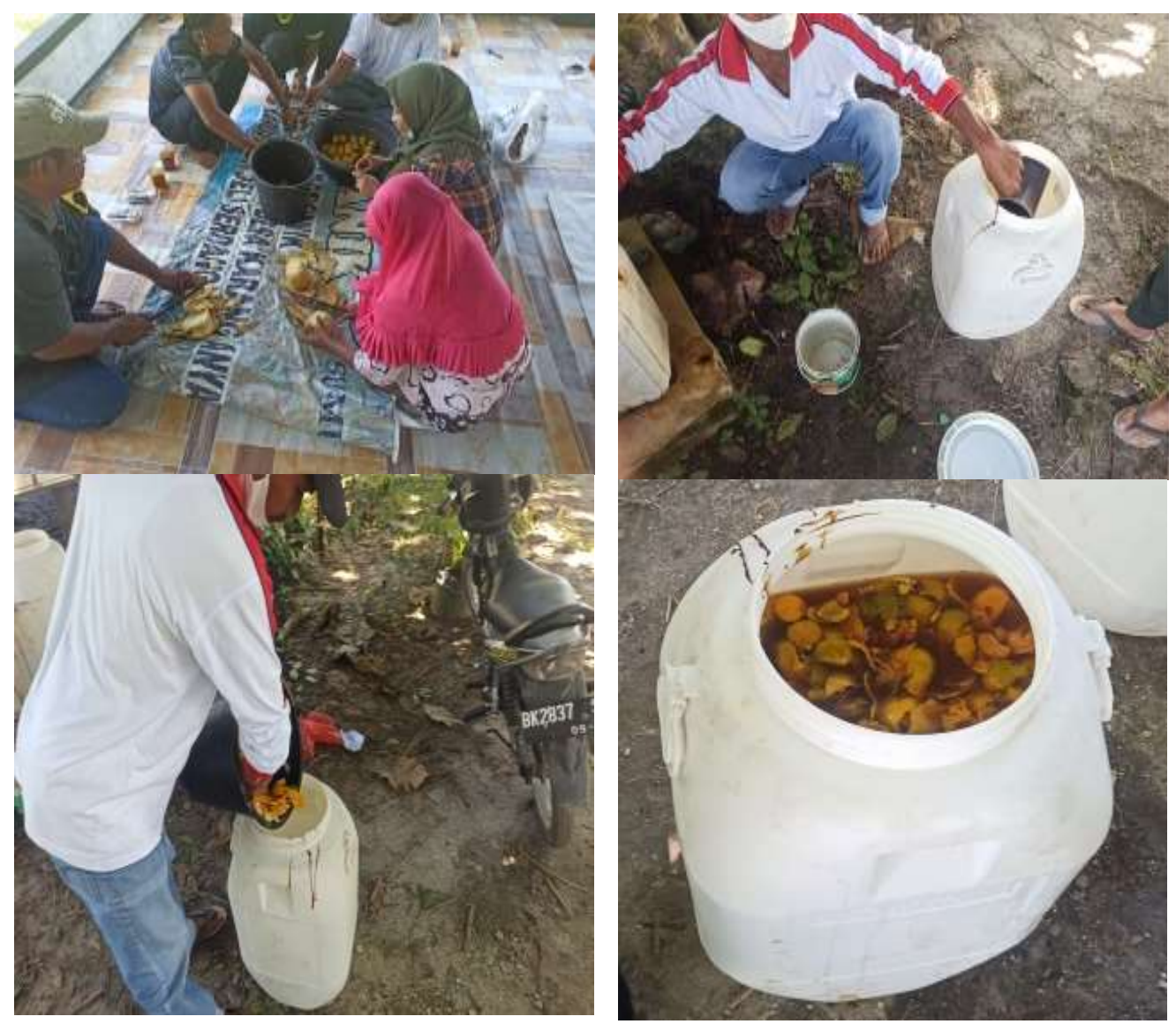

Figure 2. Making eco enzyme for liquid organic fertilizer and disinfectant

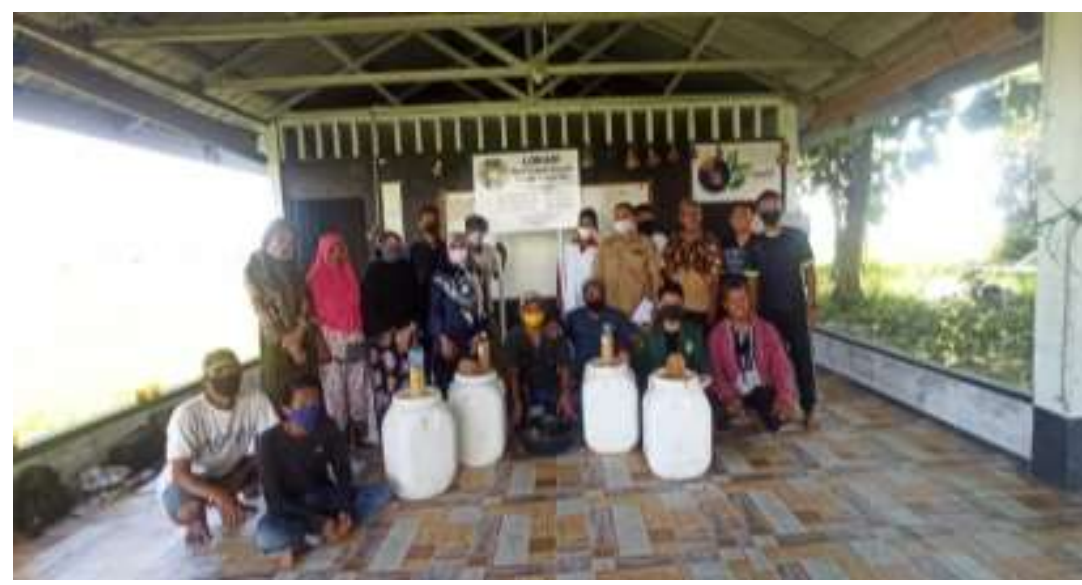

Figure 3. Community service team from USU and participants

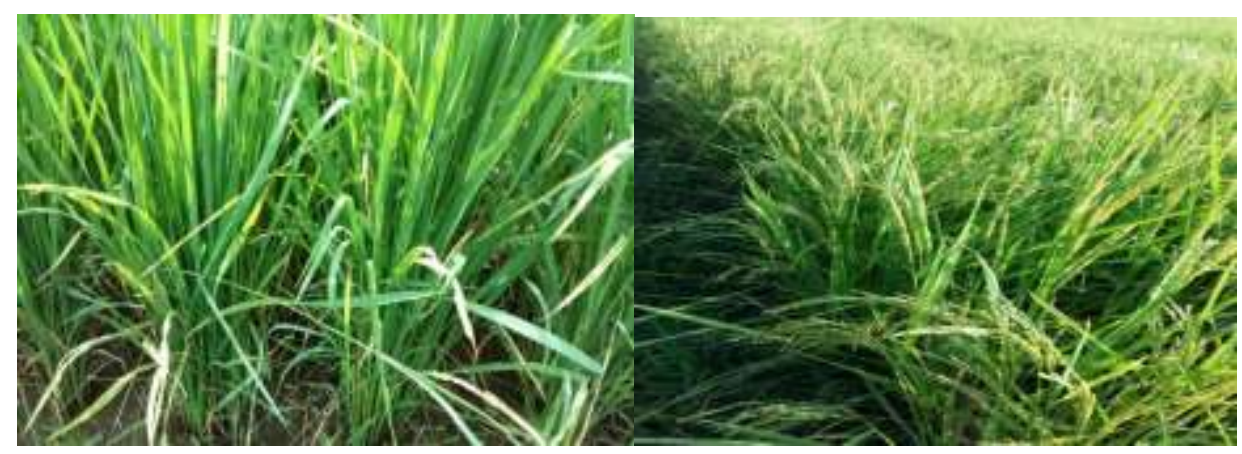

Figure 4. Organic rice plant with eco enzyme treatment 
After completing the eco enzyme fermentation, the eco enzyme's nutrient content testing was carried out in the Socfind Laboratory-Medan. The analysis results show that a $\mathrm{pH} 4.16$; C-organic $0.90 \%$; N $0.09 \%$; P $0.01 \%$; K $0.12 \%$.

Based on the observations on rice growing by using eco enzyme treatment, there was an increase in the number of tillers, namely 35 tillers at 50 days after sowing (DAS), whereas without eco enzyme treatment only 28 tillers. It is related to the process of organic decomposition and nutrient availability in the soil. Besides, the number of tillers is influenced by the increase in N's availability. $\mathrm{N}$ nutrient absorbed by plant roots increases, resulting in the compound of $\mathrm{N}$ content in leaves, especially chlorophyll. It is in line with [14] and [15] that increased chlorophyll content will improve photosynthesis and the result of photosynthesis content. Finally, it will increase plant growth and the number of tillers. This phenomenon is related to the nutrient $\mathrm{N}$ in its formation of organic molecules important in plants, such as amino acids, protein, enzymes, nucleic acids, chlorophyll, and essential for cleavage and cell enlargement.

\section{Conclusion}

Farmers who are members of the Mekar Pasar Kawat farmer group are very enthusiastic and can understand the training and hands-on practice of making eco enzyme and eco-enzyme-based organic rice cultivation. Exercise on the benefits of eco enzymes increases farmers' understanding of organic rice cultivation and the prevention of Covid-19 transmission. Organic rice cultivation based on the eco enzyme that produces organic rice is a superior product in Deli Serdang. One way to increase the income of farmer group communities, improve nutritional status, open business opportunities and protect the environment because organic rice is proven to be environmentally friendly.

\section{Acknowledgements}

The authors thank Community Service Institution, Universitas Sumatera Utara for funding this activity under the Letter of Assignment of Community Service Implementation Regular Mono Year Program, Fiscal Year 2020 Number: 287/UN5.2.3.2.1/ PPM/ 2020, dated June 9, 2020. The author also thank M. Toha and Agus Setiawan Syahputra for his assistance in the community service activity.

\section{References}

[1] A. Fairuza, "Persebaran COVID-19 Tanggal 3 April-20 April 2020 di Prov. SUMUT." Geo Spasial, vol. 18, no. 1, pp 7-11, 2020. 
[2] H, Mayrowani, "The Development of Organic Agriculture in Indonesia. Forum Penelitian Agro Ekonomi, vol. 30, no. 2, pp. 91-108, 2012, doi: 10.21082/fae.v30n2.2012.91-108. (In Indonesia)

[3] IFOAM, The World of Organic Agriculture - Statistics \& Emerging Trends. 2008. http://www.soel.de/fachtheraaii downloads/s_74_l O.pdf

[4] D. Verma, A.N. Singh, A.N. Skhula, "Use of Garbage Enzyme for Treatment of Waste Water." International Journal of Scientific Research and Review, vol. 7, no. 7, pp. 201-205, 2019.

[5] F.E. Tang, and C.W. Tong, "A study of the garbage enzyme's effects in domestic wastewater." World Academy of Science, Engineering and Technology, vol. 60, pp.1143-1148, 2011.

[6] S.S. Kerkar, and S.S. Salvi, "Application of Eco-Enzyme for Domestic Waste Water Treatment." International Journal for Research in Engineering Application and Management, vol. 5, no. 11, pp. 114-116, 2020, doi: 10.35291/2454-9150.2020.0075.

[7] Dhiman, "Eco-Enzyme-A Perfect House-Hold Organic Cleanser." International Journal of Engineering Technology, Management and Applied Sciences, vol. 5, no. 11, pp. 19-23, 2017.

[8] N. Rasit, L.H. Fern, W.A.W. Karim Ghani, "Production and Characterization of Eco Enzyme Produced from Tomato and Orange Wastes and Its Influence on the Aquaculture Sludge." International Journal of Civil Engineering and Technology, vol. 10, no. 3, pp. 967-980, 2019.

[9] M. Hemalatha, and P. Visantini, "Potential use of eco-enzyme for the treatment of metal-based effluent." In The Third Bioprocessing and Biomanufacturing Symposium 2019, IOP Conf. Series: Materials Science and Engineering, vol. 716, 012016, 2020, doi: 10.1088/1757-899X/716/1/012016.

[10] C. Arun, and P. Sivashanmugam, "Investigation of biocatalytic potential of garbage enzyme and its influence on stabilization of industrial waste activated sludge." Process Safety and Environmental Protection, vol. 94, pp. 471-478, 2015, doi: 10.1016/j.psep.2014.10.008.

[11] B.D.C. Penmatsa, B.S. Sekhar, T.V. Diwakar, Nagalakshmi, "Effect of Bio-Enzyme in the Treatment of Fresh Water Bodies." International Journal of Recent Technology and Engineering (IJRTE), vol. 8, no. 1S3, pp. 308-310, 2019.

[12] A. Lomo, "Eco enzyme." Available: http://cybex.pertanian.go.id/mobile/artikel/90961/Eco-Enzyme/, 2020. [Accessed: April 20, 2020]

[13] Y. Tong, and B. Liu, "Test research of different material made garbage enzyme's effect to soil total nitrogen and organic matter." In The 4th International Workshop on Renewable Energy and Development (IWRED 2020), IOP Conf. Series: Earth and Environmental Science, vol. 510, 042015, 2020, doi: 10.1088/1755-1315/510/4/042015.

[14] Muijiono, Tarjoko, Suyono, B.S. Indaryanto, "Assembly of Organic Rice Production Technology Based on Liquid Organic Fertilizer and Botanical Pesticide." J. Agroland, vol. 18, no. 3, pp. 162 - 168, 2011. (In Indonesia)

[15] J. Ginting, "Effect of liquid organic fertilizer on the rice varieties field production." In AEFS 2018, IOP Conf. Series: Earth and Environmental Science, vol. 260, 012177, 2019, doi: 10.1088/1755-1315/260/1/012177. 